Vol. 7(3), pp. 043-052, August, 2018

ISSN: 2354-2276

Copyright $\odot 2018$, the copyright of this article is retained by the author(s)

DOI Link: http://doi.org/10.15580/GJEMPS.2018.3.070318092

http://gjournals.org/ GJEMPS

\title{
Assessment of Benthic Macro- invertebrate Communities in Relation to Water Quality in Teltele Stream, Ambo West Showa, Ethiopia
}

\section{Gurmessa Tessema and Agumassie Tesfahun*}

\author{
Department of Biology, College of Natural and Computational Sciences, Ambo University, \\ P. O. Box 19, Ambo, Ethiopia.
}

Article No.: 070318092

Type: Research

DOI: 10.15580/GJEMPS.2018.3.070318092

Submitted: 03/07/2018

Accepted: $24 / 07 / 2018$

Published: 01/08/2018

${ }^{*}$ Corresponding Author

Agumassie Tesfahun

E-mail: agumas2012@yahoo.com

Phone: +251916184242

Keywords:

Benthic macro-invertebrates, Shannon diversity index, Teltele Stream, West

Showa
The assessment of benthic macro-invertebrates were studied in Teltele stream based on total of 6 orders and 11 families collected through December-May, 2015. Microsoft Excel and PAST software were employed to investigate the abundance and diversity of macro-invertebrates. Ephemeroptera was dominated $137(40.53 \%)$ followed by Coleoptera 112(33.14\%) in the Teletele stream. However, other groups had less distribution. Based on the study sites, Ephemeroptera, Coleoptera and Diptera were the most widely distributed organisms accounted for $69(60 \%)$ at site $1,28(17.1 \%)$ at site 2 and $40(67.8 \%)$ at site 3 for Ephemeroptera. Coleoptera comprised 22(19.1\%) at site 1 and 90(54.87\%) at site 2 and Diptera consisted $34(20.7 \%)$ at site 2 and $15(25.4 \%)$ at site 3 . The distributions and compositions of the benthic macro-invertebrates were unequal at the sampling sites and statistically not significant (one way ANOVA, P>0.05). The Shannon diversity indexes were different among the sampling sites and the distribution of benthic organisms strongly associated with water quality parameters. The overall Shannon diversity index was (1.37) it revealed that the abundance and diversity of macro-invertebrate communities were low and therefore showed that poor water quality. At the study sites, several human induced associated impact problems like the existence of exotic Eucalyptus trees, Agricultural lands, waste material disposal and Ambo University's oxidation pond were identified that resulted less distribution of macro-invertebrates in Teltele stream. The stream is vital for socioeconomic purposes such as drinking (cattle watering), sanitation, recreation, irrigation and others of the communities around the catchment and therefore, watershed management throughout the catchment is vital for proper utilization of the Teltele stream. 


\section{INTRODUCTION}

Benthic macro-invertebrates can survive in different habitats such as at the bottom of rivers, lakes and reservoirs and they are correlated with different aspects of substrates like sediments, detritus, macrophytes and filamentous algae (Tesfay et al., 2017). Macroinvertebrates are critical elements in both running and standing water systems as in the energy flow and nutrient recycling during food web interaction as well as they are also vital food items for fishes and other insectivorous aquatic animals (Ward et al., 1995). Moreover, the macro-invertebrates have been provided most reliable information as bio-indicator by assessing long term ecological changes in the quality of aquatic ecosystems (Whiles and Wallace, 1997). The abundance and diversity of benthic macro-invertebrates are vital to predict the water quality of given water bodies (Teferi et al., 2013). Moreover, they are important in the energy flow and nutrient re-cycling in lentic and lotic water bodies (Tesfay et al., 2016).

Human beings need water for various purposes apart from drinking and body functions. Fresh water is among the most used of the world's resources (Bunn et al., 1999). Rivers and streams are vital freshwater systems that are critical for the sustenance of life (Rosenberg and Resh, 1993). In Ethiopia, these freshwater resources are the most important and being used for a variety of life purposes. Ethiopia, with its different geological formations and climatic conditions endowed with considerable water resources. The total runoff from its twelve river basins is estimated at 122 billion cubic meters of water per year (Zinabu and Elias, 1989). In villages of Ethiopia, water used for human consumption, drinking, bathing, laundry, preparation of food etc, is obtained from rivers, streams, shallow wells, springs, lakes, ponds, and rainfall. However, the environment, economic growth and development of Ethiopia are highly influenced by water. Consequently, deforestation in the headwaters, erosion, siltation, domestic and industrial wastes, agricultural activities and diversions are the most important threats to degradation of surface water in general and streams and rivers in particular (Zinabu and Elias, 1989; Aschalew, 2015). These threats have numerous impacts including partial or total destruction of natural river biota, alterations to river functioning, over loading of self-cleansing mechanisms and associated drastic lowering of water quality. These alterations cause adverse affects such as impacts on human health, increased water treatment costs and reduction of fish production potential (Aschalew and Moog, 2015). The main causes for contaminants of these water sources are agricultural activities, human excreta because of open field defecation practices, animal waste, and effluent from urban or industries (Aschalew and Moog, 2015; Mulugeta, 2010).

Several studies were conducted in Ethiopian running water bodies with regard to spatial distribution of benthic macro-invertebrates and their stressors as stream health indicators (Negero et al., 2017; Getachew et al., 2012; Lakew, 2015; Tamiru et al., 2017; Teferi et al., 2013; Tesfay et al., 2016; Wolemariam et al., 2018; Worku and Ambelu, 2018).

However, there is no sufficient information on the assessment of benthic macro-invertebrate community structures in Teltele stream, which gives the general knowledge on water quality status for the socio-economic purposes in the country (Ambo Town). Therefore, the present study was conducted to fill this gap and to provide useful information for the proper management of the stream to continued socioeconomic purposes.

\section{MATERIALS AND METHODS}

\subsection{Description of the Study Area}

The study area, Teltele stream is found in Ambo town, which is located about $114 \mathrm{~km}$ West from Addis Ababa the capital city of Ethiopia. Ambo, which is popular for its immense natural gifts including excellent climate which provides comfortable living and working environment. Teltele stream is a tributary of Huluka river and originates from Wenchi and flows through the Western part of Ambo town towards Abay drainage basin. The study was conducted at three sites namely, site1 (latitude $9^{\circ} 04^{\prime} 15.8$, longitude $38^{\circ} 08^{\prime} 22.4$ and 2376 m.a.s.l), site 2 (latitude $9^{\circ} 4^{\prime} 49.5$, longitude $38^{\circ} 8^{\prime} 15.7$ and 245 m.a.s.l) and site 3 (latitude $9^{\circ} 3^{\prime} 53.9$, longitude $38^{\circ} 07^{\prime} 49.8$ and 2331 m.a.s.l). The upstream section of Teltele stream is dominated by indigenous trees and in downstream occupied Eucalyptus trees.

Furthermore, the date of sampling depends on the objective of the study and climate conditions. For instance, variability of discharge volume of streams caused by seasonal changes affect the distribution pattern of benthic macro-invertebrates and limit accessibility to sampling sites. For this reason, it is usually recommended to avoid sampling during high water levels and shortly after flooding. With this sense, our sampling conducted in the dry season to insure low water level and regeneration of BMI (benthic macro-invertebrates index) after heavy flooding months. A representative stream sections were selected within $100 \mathrm{~m}$ gaps for each stream. Substrate composition of each site was visually estimated in accordance with particle size (e.g. micro-lithal, mesolithal, macro-lithal etc.). 


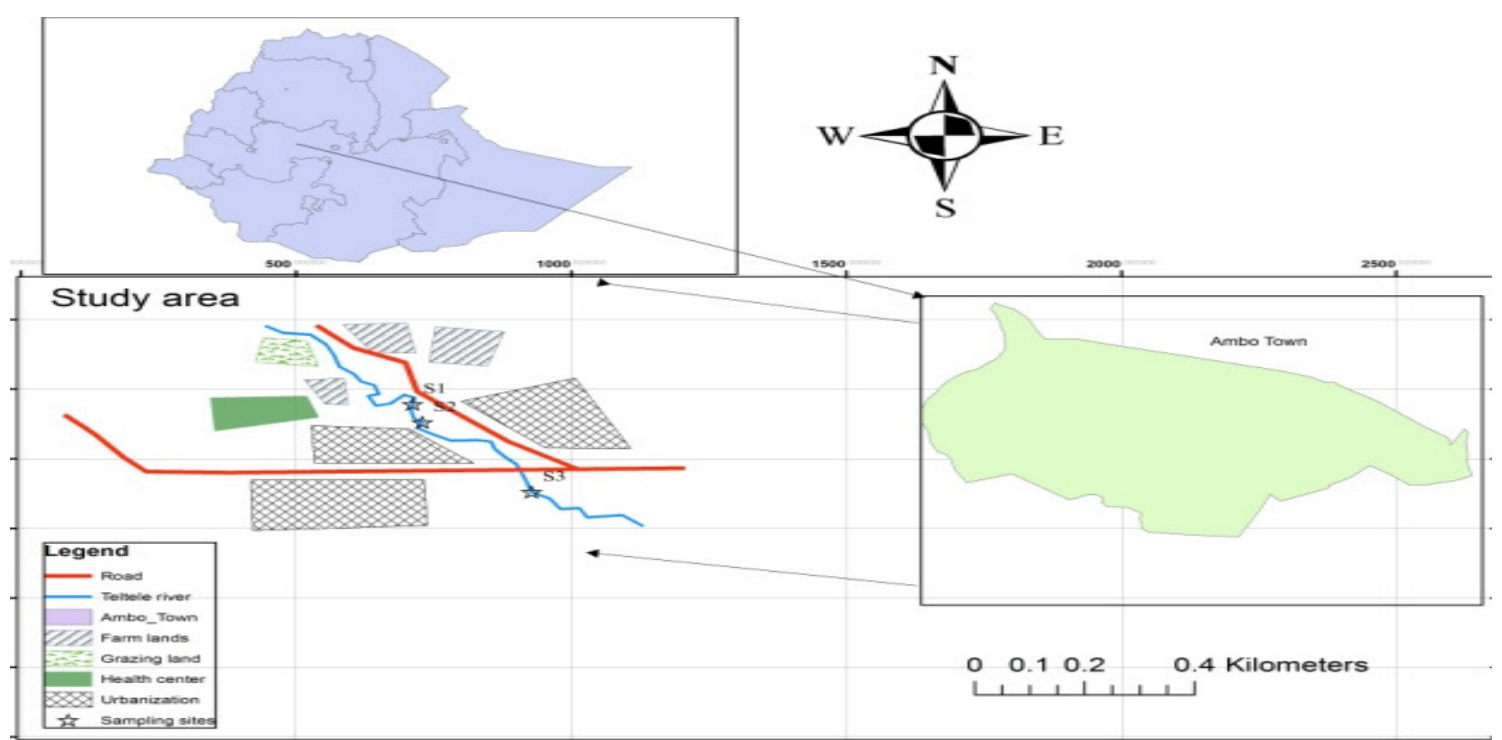

Figure 1: Map of the study area in relation to Ambo town, land use practices and sampling sites (s1=sampling site $1, s 2=$ sampling site 2 and s3=sampling site 3 )
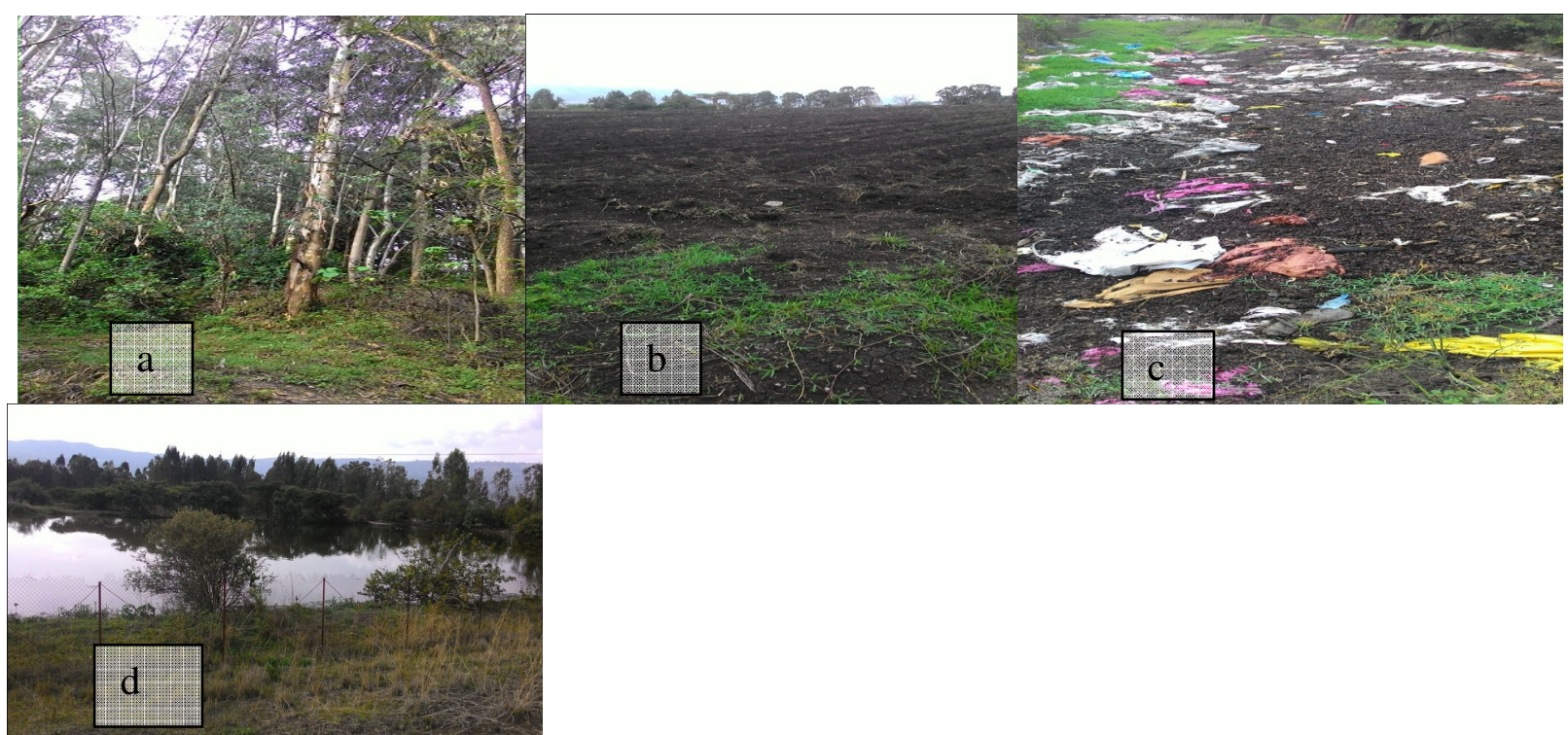

Figure 2: Land use practices ( $a=$ Eucalyptus trees, $b=$ farming lands, $c=$ waste disposal, $d=A m b o$ University's oxidation pond) involved via the catchment of the Teltele Stream

\subsection{Macro-invertebrates sample collection}

Macro-invertebrates were collected by using standard hand net with frame width of $25 \times 25 \mathrm{~cm}^{2}$ and mesh size of $500 \mu \mathrm{m}$. Single habitat sampling method is emphasized especially to riffle and runs as means of standardize assessment in the streams which have those habitats. This approach is important because of, macro-invertebrates diversity and abundance are usually highest in cobble substrate (riffle/run) habitats (Plafkin, 1989).11 family samples were collected from all habitat types with a share of at least $5 \%$ habitat coverage in selected stream section each sample was collected by positioning the net and disturbing the substrate in a quadratic area that equals the frame area of the net. Sampling was begun at the downstream end of the reach and preceded upstream against the current. In places where the current becomes low, hand stirrings was used to create local currents to push the organisms into the net. Mega-lithal stones are sampled by brushing their surfaces approximately equal to the size of the sampling net. Macro-lithal stones picked by hand and their surfaces were brushed to dislodge clingers and sessile organisms. After every 3 sampling, the net was rinsed by running clean stream water to avoid clogging which could interfere with obtaining an appropriate sample. Before preservation, quick identification of major taxa was performed on site as a quality assurance. Samples were then preserved in (4\%) formaldehyde and label was placed inside the 
plastic container marked with date, stream name and site identity code. The same information was labelled on

the outside of the container with water proof markers.

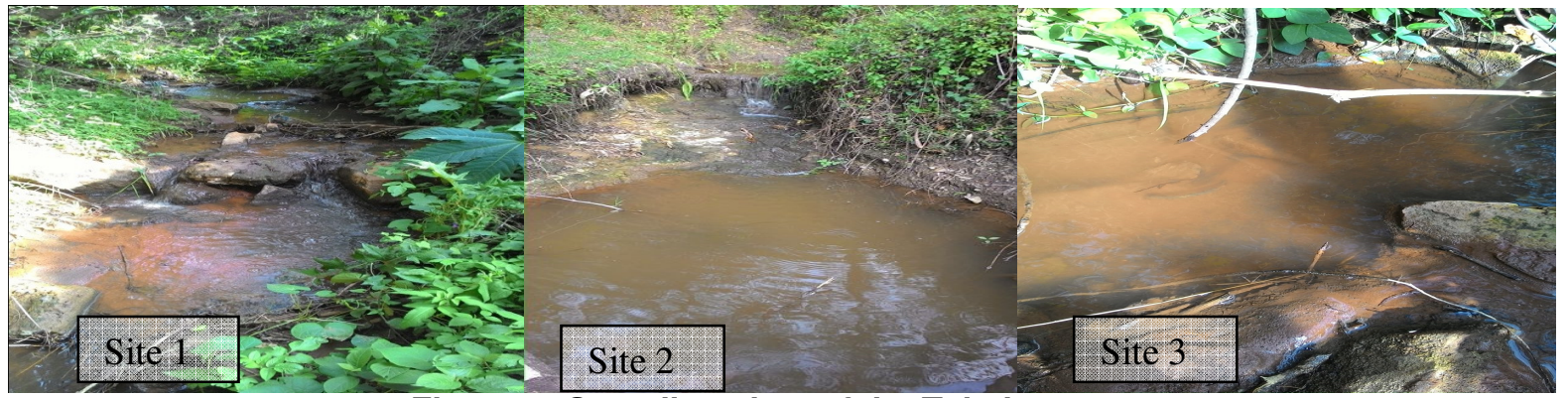

Figure 4: Sampling sites of the Teltele stream

\subsection{Laboratory Analysis and Identification of Macro- invertebrates}

The preserved macro-invertebrate samples were processed in the laboratory for further analysis. All information from the sample container was carefully copied to the sample log sheet. A complete sample was passed through a set of sieves $(5000,3000,2000$, 1000 and $500 \mu \mathrm{m}$ mesh size) in order to remove formalin and separate size classes of macro-invertebrate groups under tap water. Macro-invertebrates trapped in the coarse fraction of the sieve was sorted completely in the laboratory using naked eyes while organisms trapped in the smaller fraction of the sieve was sorted with the help of dissecting microscope. Subsampling was applied to according to Barbour et al. (1999). Identification was performed based on the South African aquatic invertebrates identification key (Gerber and Gabriel, 2002). All macro-invertebrates were identified to family level at Ambo University, Biology laboratory (Figure 5).

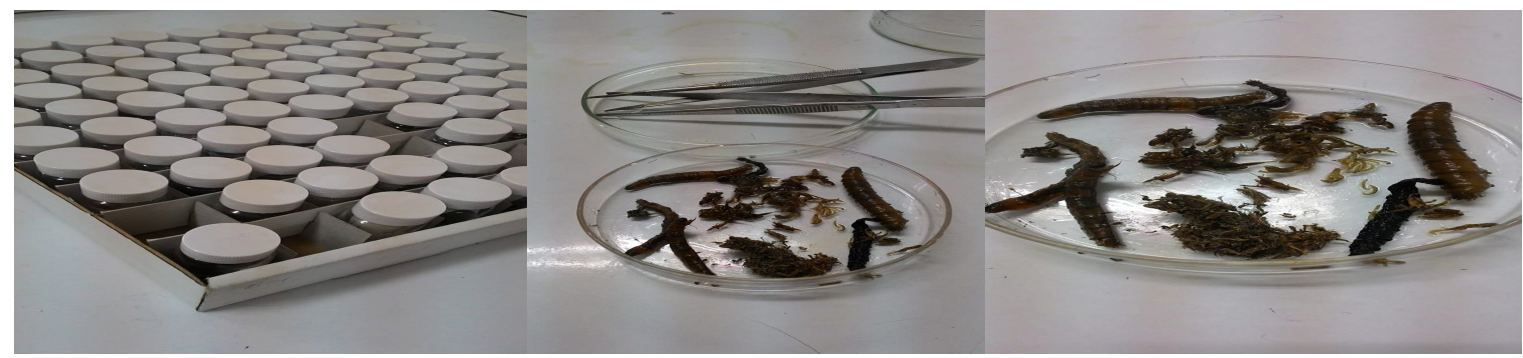

Figure 5: Some laboratory protocols in Biology laboratory at Ambo University

\section{DATA ANALYSIS}

Descriptive statistics, Shannon diversity index, Margalef index, species evenness and one way ANOVA were used to compute the diversity and abundance of macroinvertebrates in and at the sampling sites of the Teletele stream by using PAST software version 011.

\section{RESULTS}

The physico-chemical (mean $\pm \mathrm{SD}$ ) of (DO) $\mathrm{mg} / \mathrm{L}$, (conductivity) $\mu \mathrm{S} / \mathrm{cm}$, (Temperature) ${ }^{\circ} \mathrm{C}$, (TDS) $\mathrm{m} / \mathrm{L}$ and $\mathrm{NO}_{3}$ etc water quality parameters of Teltele stream were given at the three sites (Table 1). The distribution, abundance and diversity of benthic macro-invertebrates were positively correlated with water quality parameters such as $\mathrm{p}^{\mathrm{H}}$, dissolved oxygen, total nitrogen, total phosphorus and temperature as well as statistically significant (one way ANOVA, $p<0.05$ ).

A total of 338 macroinvertebrates classified into 6 orders and 11 families of macroinvertebrates were collected from the 3 sampling sites in Teltele stream. The most abundant orders were Ephemeroptera $137(40.53 \%)$ represented by Baetidae family, Coleoptera 112(33.13\%) represented by Hydrophilidae family, Diptera 55(16.27\%) represented by 4 families namely, Chironomidae 46(13.6\%), Syrphidae 1(0.3\%), Tipulidae 6(1.78\%) and Tabanidae 2(0.6\%), Odonata $13(3.84 \%)$ denoted by Coanagrionidae $9(2.7 \%)$ and Libellulidae $4(1.2 \%)$ families, Gastropoda 11(3.25\%) represented by 2 families like Physidae 6(1.8\%) and Planorbidae 5(1.5\%) and Oligochaeta 10(2.96\%) represented by 1 family (Table 2). Orders namely Ephemeroptera, 69(60\%), 28(17.1\%) and 40(67.8\%) were mostly found at site1, 2 and 3 respectively (Figure 6). Similarly, Diptera accounted for $34(20.7 \%)$ at site 2 
and $12(25.4 \%)$ at site 3 . In the same way, Coleoptera comprised $22(19.1 \%)$ at site 1 and $90(54.88 \%)$ at site 2 . Shannon diversity index of macro-invertebrate communities were (1.2), (1.19) and (0.79) at site 1,2 and 3 respectively however, it was insignificant (one way ANOVA, P>0.05) (Table 3). Relatively, the highest Shannon diversity index (1.2) and (1.19) was recorded at site 1 and site 2 respectively. In similar manner, better Margalef index (1.1) and (0.78) was recorded at site 1 and site 2. In other words, site 1 and site 2 had highest species richness and however, site 3 had less species richness due to less Shannon diversity index (0.79). Species evenness values were organized in a similar pattern (0.6), (0.7) and (0.7) at site 1, site 2 and site 3 respectively (Table 4$)$. The overall, Shannon diversity index was (1.37), species evenness value (0.7) and Margalef index value (0.86) in the stream (Table 4).

Table 1: Physico-chemical parameters at each sampling sites in Teltele stream

\begin{tabular}{llll}
\hline \multicolumn{1}{c}{ Parameters } & Site I & Site II & Site III \\
\hline Dissolved Oxygen & $10.4 \pm 0.214$ & $9.75 \pm 0.55$ & $9.38 \pm 0.621$ \\
$\mathrm{NO}_{3}-\mathrm{N}$ & $0.67 \pm 0.061$ & $0.64 \pm 0.049$ & $0.58 \pm 0.004$ \\
Chloride & $5.83 \pm 0.711$ & $6.33 \pm 0.54$ & $6.50 \pm 0.353$ \\
Total hardness & $137.25 \pm 2.165$ & $138 \pm 2.828$ & $146.25 \pm 4.603$ \\
Total dissolved solids & $304.25 \pm 2.278$ & $315.5 \pm 1.803$ & $320.5 \pm 1.118$ \\
Total phosphorous & $0.121 \pm 0.032$ & $0.109 \pm 0.014$ & $0.064 \pm 0.022$ \\
Temperature & $20.275 \pm 1.492$ & $19.525 \pm 0.942$ & $19.4 \pm 0.982$ \\
PH & $7.7 \pm 0.187$ & $7.77 \pm 0.109$ & $7.92 \pm 0.148$ \\
BOD & $4 \pm 0$ & $8 \pm 0$ & $24 \pm 0$ \\
\hline
\end{tabular}

Source :( Hirpa, 2012)

Table 2: Relative abundance of the main taxonomic groups of macroinvertebrates at each sampling station inTeltele Stream

\begin{tabular}{|c|c|c|c|c|}
\hline $\begin{array}{c}\text { Sampling } \\
\text { Sites }\end{array}$ & Order & $\begin{array}{c}\text { Order in } \\
(\%)\end{array}$ & Families & Families in (\%) \\
\hline Site 1 & Ephemeroptera & 60 & Baetidae & 60 \\
\hline Site 1 & Diptera & 5.21 & Chironomidae & 3.5 \\
\hline Site 1 & Diptera & 5.21 & Syrphidae & 0 \\
\hline Site 1 & Diptera & 5.21 & Tipulidae & 1.74 \\
\hline Site 1 & Diptera & 5.21 & Tabanidae & 0 \\
\hline Site 1 & Coleoptera & 19.13 & Hydrophilidae & 19.13 \\
\hline Site 1 & Odonata & 7.8 & Coanagrionidae & 7.8 \\
\hline Site 1 & Odonata & 7.8 & Libellulidae & 0 \\
\hline Site 1 & Gastropod & 6.96 & Physidae & 4.35 \\
\hline Site 1 & Gastropod & 6.96 & Planorbidae & 2.68 \\
\hline Site 1 & Oligochaeta & 0.87 & Tubificidae & 0.87 \\
\hline Site 2 & Ephemeroptera & 17.1 & Baetidae & 17.1 \\
\hline Site 2 & Diptera & 20.7 & Chironomidae & 18.29 \\
\hline Site 2 & Diptera & 20.7 & Syrphidae & 0 \\
\hline
\end{tabular}




\begin{tabular}{|c|c|c|c|c|} 
Site 2 & Diptera & 20.7 & Tipulidae & 1.23 \\
\hline Site 2 & Diptera & 20.7 & Tabanidae & 1.23 \\
\hline Site 2 & Coleoptera & 54.9 & Hydrophilidae & 54.9 \\
\hline Site 2 & Odonata & 0 & Coanagrionidae & 0 \\
\hline Site 2 & Odonata & 0 & Libellulidae & 0 \\
\hline Site 2 & Gastropod & 1.83 & Physidae & 0.61 \\
\hline Site 2 & Gastropod & 1.83 & Planorbidae & 1.23 \\
\hline Site 2 & Oligochaeta & 5.5 & Tubificidae & 5.5 \\
\hline Site 3 & Ephemeroptera & 67.8 & Baetidae & 67.8 \\
\hline Site 3 & Diptera & 25.4 & Chironomidae & 20.34 \\
\hline Site 3 & Diptera & 25.4 & Syrphidae & 1.69 \\
\hline Site 3 & Diptera & 25.4 & Tipulidae & 3.4 \\
\hline Site 3 & Diptera & 25.4 & Tabanidae & 0 \\
\hline Site 3 & Coleoptera & 0 & Hydrophilidae & 0 \\
\hline Site 3 & Odonata & 6.78 & Coanagrionidae & 0 \\
\hline Site 3 & Odonata & 6.78 & Libellulidae & 6.78 \\
\hline Site 3 & Gastropod & 0 & Physidae & 0 \\
\hline Site 3 & Gastropod & 0 & Planorbidae & 0 \\
\hline Site 3 & Oligochaeta & 0 & Tubificidae & 0 \\
\hline
\end{tabular}

Table 3: Shannon diversity (H), Margalef index (d), number of individual (N), species richness (S), species evenness $(J)$ and Dominance (D) of macroinvertebrates in stream at each site

\begin{tabular}{|c|c|c|c|}
\hline & site_1 & site_2 & site_3 \\
\hline Taxa_S & 6 & 5 & 3 \\
\hline Individuals & 115 & 164 & 59 \\
\hline Dominance_D & 0.4104 & 0.3766 & 0.5289 \\
\hline Simpson_1-D & 0.5896 & 0.6234 & 0.4711 \\
\hline Shannon_H & 1.203 & 1.19 & 0.7941 \\
\hline Evenness_e^H/S & 0.555 & 0.6573 & 0.7375 \\
\hline Brillouin & 1.124 & 1.138 & 0.7311 \\
\hline Menhinick & 0.5595 & 0.3904 & 0.3906 \\
\hline Margalef & 1.054 & 0.7843 & 0.4905 \\
\hline Equitability_J & 0.6714 & 0.7393 & 0.7228 \\
\hline Fisher_alpha & 1.345 & 0.9743 & 0.6678 \\
\hline Berger-Parker & 0.6 & 0.5488 & 0.678 \\
\hline
\end{tabular}


Table 4: Shannon diversity $(H)$, Margalef index (d), number of individual

$(N)$, species richness (S), species evenness (J) and Dominance (D) of macro-invertebrates in stream (stream wise)

\begin{tabular}{|c|c|}
\hline & Values \\
\hline Taxa_S & 6 \\
\hline Individuals & 338 \\
\hline Dominance_D & 0.304 \\
\hline Simpson_1-D & 0.696 \\
\hline Shannon_H & 1.368 \\
\hline Evenness_e^H/S & 0.6549 \\
\hline Brillouin & 1.332 \\
\hline Menhinick & 0.3264 \\
\hline Margalef & 0.8587 \\
\hline Equitability_J & 0.7637 \\
\hline Fisher_alpha & 1.036 \\
\hline Berger-Parker & 0.4053 \\
\hline
\end{tabular}

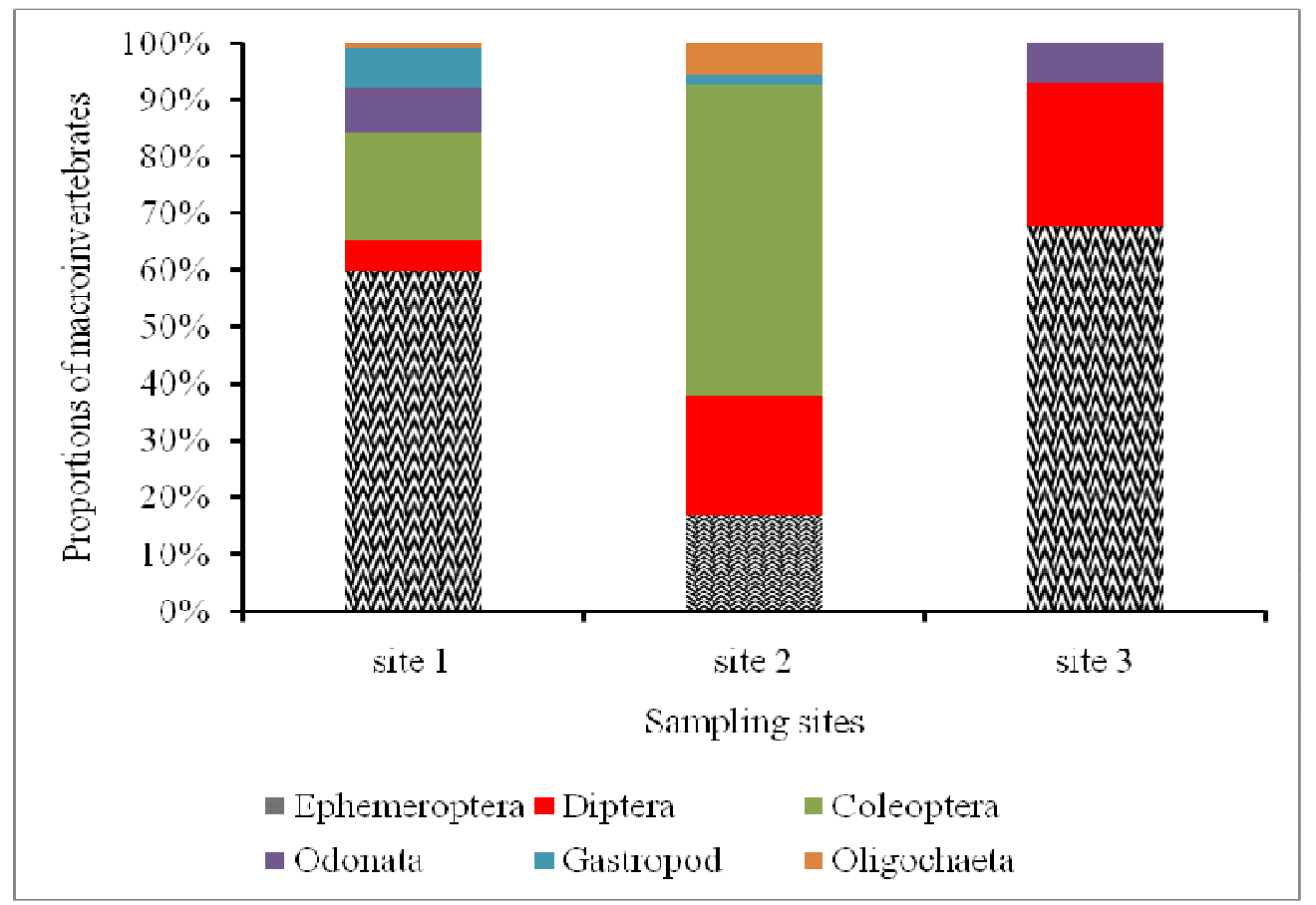

Figure 6: Relative abundance of the main taxonomic groups of macroinvertebrates at each sampling station inTeltele Stream

\section{DISCUSSION}

In this study 6 orders and 11 families were identified. However, the macro-invertebrate communities composition were lowest when compared to related findings e.g. 10 orders and 37 families in the spring and stream sites of the upper Awash River (Negero et al., 2017), 10 orders and 34 families in Cheffa wetland from Borkena Valley (Getachew et al., 2012), 9 orders and 34 families in Wedech River in Debrezeit (Tamiru et al., 2017), 12 orders 33 families in highland stream of
Northern Ethiopia (Teferi et al., 2017),7 orders and 20 families in Enda Gabr stream in Mekele Northern Ethiopia (Tesfay et al., 2016), 20 families in Northern highland of Ethiopia (Wolemariam et al., 2018) and 9 orders and 36 families in Southwestern Ethiopia (Worku and Ambelu, 2018) were documented. Moreover, the present finding not agrees with (Hirpa, 2012) in the same study area where 6 orders and 21 families of benthic macro-invertebrates were investigated. The differences of macro-invertebrates composition in the present study might be attributes that which was conducted at the 
downstream. The presence of less benthic macroinvertebrate communities were most probably indicates that poor water quality. This is because the Teltele stream which is exposed by land use practices such as farming, the impact of Ambo University's oxidation pond, the disposal of the liquid and solid waste, and the plantation of Eucalyptus trees particularly at the sampling sites (Figure 2, a-d). For instance, in the Southern streams of Gilgel Gibe River the values of the total nitrogen, total phosphorus and $\mathrm{pH}$ were low under the streams of Eucalyptus tree. This is might be due to reducing of nutrient cycling by Eucalyptus tree due to phenolic acid released from Eucalyptus leaf as it was reported by (Worku and Ambelu, 2018; Jiregna, 2003) and this is might be true for the present study. ShannonWiener diversity index values among stations were different probably due to the presence of livestock grazing around and other anthropogenic activities have direct impacts on the macro-invertebrate communities in streams (Hynes, 1970; Nedeau, 2003; Azrina et al., 2006; Hamilton, 2008). Several studies pointed out that the interaction of physical and chemical of the water quality parameters (Minshall et al., 1985; Meyer, 1997), biological parameters (Dauer, 1983; Teshome et al., 2015) and the human pressure through water catchments (Mohammed and Uraguchi, 2013) can determine the survival and the fitness of macroinvertebrates in the water bodies either lotic or lentic. For instance, biological factors, such as availability of predators in the water, macro-invertebrates behavior towards the trap gear, shape, and external features, which depends on season, environment and other species, determine the composition and distribution in the catch (Petts et al., 1993; Bode, 1996; Blumenfeld et al., 2009). The environmental factors, such as water temperature (Karr, 1999; Maddock, 1999) and water salinity (Hofer et al., 2007) also influence the composition of the required data (Table 1). According to Tesfay et al. (2017), Ephemeropterans, Plecoptera and Trichopterans (EPT) are very important in assessing water quality as they show low tolerance toward water pollutants. These organisms are sensitive to environmental changes that may occur in clean and well oxygenated waters. Therefore, EPT assemblages are frequently considered as good indicators for water quality. However, in the present study Plecoptera and Tricoptera were not recorded this might be revealed that water quality changes at the study area. Many sites of Teltele stream the values are below 1.5 level of the Shannon diversity index, this indicates presence degraded macro or micro habitats that resulted less macro-invertebrate communities in terms of abundance and diversity. This is because, most values measured using the Shannon diversity index range from (1.5-3.5). Besides, values above (3.0) indicate that the habitat structure is stable and balanced and values. On other hand, values under (1.0) indicate the presence of pollution and degradation of habitat structure by human induced and natural associated impacts in or near by the catchments of the stream. Based on these criteria, at site 3, had lowest Shannon diversity index (0.79) the implication is at this site there is water quality change (pollution) resulted in less abundance and diversity of benthic macro-invertebrates. In summary, water quality, macro-invertebrates diversity, and habitat conditions of Teltele stream were impacted by anthropogenic activities at all sites activities related with urbanization such as disposal of solid and liquid wastes, animal wastes, vehicle washing and agricultural activities those activities alter the water quality this in turn resulted less aquatic community structure and it can impaired the given stream.

\section{CONCLUSIONS}

The Shannon diversity index in Teltele stream (1.37) showed that less abundance and diversity of benthic fauna. Because of typical values are generally between 1.5 and 3.5 in most ecological studies for abundance and diversity, if not the index value is less than 1.5. The lower diversity and biotic indices values indicated poor water quality. Only 338 macro-invertebrate samples were collected from this study this is due to anthropogenic impacts this in turn impaired the water quality. Land use practices along the catchment of the stream strongly affected, macro-invertebrate community structure and biodiversity. The stream is vital for socioeconomic purposes such as drinking (cattle watering), sanitation, recreation, irrigation and others of the communities around the catchment and therefore, watershed management throughout the catchment is vital for proper utilization of the Teltele stream.

\section{ACKNOWLEDGMENTS}

The authors would like to appreciate Department of Biology, College of Natural and Computational sciences, Ambo University, for laboratory facilities.

\section{CONFLICT OF INTEREST}

Authors have declared that there is no conflict of interest.

\section{REFERENCES}

1. Aschalew L (2012). Testing bio-assessment methods in some highlands of Ethiopia. LAPLAMBERT Academic publishing.

2. Aschalew L (2015). Assessing anthropogenic impacts using benthic macro-invertebrates as bioindicators in central highland streams of Ethiopia. Ethiopian Journal of Environmental Studies and Management, 8(1): 45-56.

3. Aschalew L, Moog $O$ (2015). A multimetric index based on benthic macro invertebrates for assessing 
the ecological status of streams and rivers in central and southeast highlands of Ethiopia". Hydrobiologia, 751(1): 229-242.

4. Azrina MZ, Yap CK, Ismail AR, Ismail A, Tan SG (2006). Anthropogenic impacts on the distribution and biodiversity of benthic macroinvertebrates and water quality of the Langat River, Peninsular Malaysia. Eco-toxicology and Environmental Safety, (64):337-347.

5. Barbour MT, Gerritsen J, Snyder BD, Stribling JB (1999). Rapid Bio-assessment Protocols for Use in Streams and Wade able Rivers. EPA/841/B99/002.US Environmental Protection Agency, Washington, DC.

6. Blumenfeld S, Lu C, Christophersen T, Coates D (2009). Water, Wetlands and Forests. "A Review of Ecological, Economic and Policy Linkages".CBD Technical Series No. 47.Montreal/Gland, Switzerland, Secretariat of the Convention on Biological Diversity and Secretariat of the Ramseur Convention on wetland.

7. Bode RW (1996). Quality assurance work plan for biological stream monitoring in New York State. NYS DEC technical report.

8. Bunn S, Davies P, Mosisch T (1999). Ecosystem measures of river health and their response to riparian and catchment degradation, Freshwater Biology, (41): 333-345.

9. Dauer DM (1983). Functional morphology and feeding behavior of Scolelepsis squamata (Polychaeta: Spionidae). Marine Biology, (77): 279285.

10. Gerber A, Gabriel MJM (2002). Aquatic invertebrates of South African Rivers. Field Guide, Institute of Water Quality Studies, Pretoria, South Africa.

11. Getachew M, Ambelu A, Tiku S, Legesse W, Adugna A, Helmut Kloos (2012). Ecological assessment of Cheffa Wetland in the Borkena Valley, northeast Ethiopia: Macroinvertebrate and bird communities. Ecological Indicators, (15): 63-71.

12. Hamilton LS. Forest and Water (2008). A Thematic Study prepared in the framework Global Forest Resource Assessment.

13. Hirpa (2012). A Study on Composition and spatial distribution of macro-benthic fauna in Teltelle stream, Ambo, Ethiopia. A MSc thesis submitted to Ambo University, 72 pp.

14. Hofer ICT, Vermont S, Warren P (2007). Towards a new understanding of forests and water.

15. Hynes HBN (1970). The Ecology of Running waters. Liverpool University Press, Ontario, 555pp.

16. Jiregna $G$ (2003). Water and nutrient relations of selected tree species of Ethiopia. PhD Dissertation, Stellenbosch University, Stellenbosch, South Africa, pp. 180.

17. Karr JR (1999). Defining and measuring river health. Freshwater Biology, 41: 221 - 234.
18. Maddock I (1999). The importance of physical habitat assessment for evaluating river health. Freshwater Biology, 41:373-391.

19. Meyer JL (1997). Stream health: incorporating the human dimension to advance stream ecology. Journal of North American Benthological Society, (16): 437-447.

20. Minshall GW, Cummins KW, Petersen RC, Cushing CE, Bruns DA, Sedell JR, Vannote RL (1985). Developments in stream ecosystem theory. Canadian Journal of Fisheries and Aquatic Sciences, 42: 1045-1055.

21. Mohammed EY, Uraguchi ZB (2013). Impacts of Climate Change on Fisheries: Implications for Food Security in Sub-Saharan Africa. In MA. Hanjra eds. Global Food Security, Nova Science Publishers, Inc, 114-135.

22. Mulugeta L (2010). Growing Eucalyptus by smallholder farmers in Ethiopia.

23. Nedeau EJ, Merritt RW, Kaufman MG (2003). The effect of an industrial effluent on an urban stream benthic community: water quality vs habitat quality. Environmental Pollution, Oxford, Elsevier, (123):113.

24. Negero, Lakew A, Prabha D and Wolfram G (2017). Macro Invertebrate Communities in the spring and Stream Sites of Upper Awash River at Chilimo, Ethiopia. Innovative Techniques in Agriculture, 1(3): 141-151.

25. Petts GE, Moller H, Roux AL (1993). Historical change in large alluvial rivers. Western Europe.

26. Plafkin JL (1989). Rapid Bio-assessment Protocols for Use in Streams and Rivers; Benthic Macroinvertebrates and Fish.U.S. E.P.A., Cincinnati, OH Publ No.EPA/440/4-89/001.

27. Rosenberg DM, Resh VH (1993). Introduction to freshwater bio monitoring and benthic macroinvertebrates. In: Rosenberg D.M. and Resh V.H (eds.): Fresh water bio monitoring and benthic Macroinvertebrates.

28. Tamiru SM, Asfaw SL, Yilma SM (2017). Correlation study of some physico-chemical parameters and benthic macroinvertebrates metrics on the ecological impacts of floriculture industries along Wedecha River, Debrezeit, Ethiopia. Journal of Coastal Life Medicine, 5(10): 433-440.

29. Teferi M, Tsegazeabe H. Haileselasie, Asmelash $T$, Haile G. Selasie, Alem G, Amare S, Weldegerima K, Tesfay S, Kiros S, Gebru (2013). Influence of water quality on the diversity and distribution of macroinvertebrates in highland stream, Northern Ethiopia. Scholarly Journal of Agricultural Science, 2(2): 1725.

30. Tesfay S, Teferi M, Aragaw Sh, Abrha W (2016). Assessment of Macroinvertebrate Communities in Enda Gabr Stream, in Mekelle, Northern Ethiopia. Journal of Natural Sciences Research, 6(19):115:125.

31. Teshome G, Getahun A, Mengist M, Hailu B (2015). Some biological aspects of spawning migratory 
Labeobarbus species in some tributary rivers of Lake Tana, Ethiopia. International Journal of fisheries and aquatic studies, 3(2):136-141.

32. Ward D, Holmes N, José P (1995). The New Rivers and wildlife hand book. Bedfordshire: RSPB, NRA, the Wildlife Trusts. pp. 426.

33. Welemariam M, Kebede F, Bedadi B and Birhane E (2018). The Effect of Community-Based Soil and Water Conservation Practices on Abundance and Diversity of Soil Macro-invertebrates in the Northern Highlands of Ethiopia. Agronomy, 8(56):2-15.
34. Whiles MR, Wallace JB (1997). Leaf litter decomposition and macroinvertebrate communities in headwater streams draining pine and hardwood catchments. Hydrobiologia, 35 (31): 107-119.

35. Worku $Y$ and Ambelu A (2018). Evaluation of the Impacts of Eucalyptus Plantation on MacroInvertebrate Assemblage in the Aquatic Environment, South Western Ethiopia. Int. J. Environ. Sci. Nat Res, 9(1):001-012.

36. Zinabu, G. and Elias, D (1989). Water resources and fisheries management in the Ethiopian rift Valley lakes. SINET: Ethiopia. J.Sc., 12 (2): 95-109. 